\title{
Education an Antidote against Early Marriage for the Girl-Child
}

Okereke Chinyere Ijeoma

\author{
Uwakwe Joseph 0. \\ Nwamuo Paul \\ School of Sciences \\ Federal College of Education (Technical), \\ Umunze-Anambra State, \\ Nigeria
}

\section{Doi:10.5901/jesr.2013.v3n5p73}

\begin{abstract}
This paper explores the reasons behind early marriage in Africa, ray Nigeria to include economic, socio-cultural and religious as well as notions of morality and honour and its devastating effects on physical, health, psycho-social as well as the education of the girl-child. While many conventions have addressed the issues of early marriage and made strong case for protection of the children's right but the country lacks political will to enforce the relevant provisions. This paper proposes education as an antidote.
\end{abstract}

\section{Introduction}

The world over, marriage is an institution and is regarded as a moment of celebration and a milestone in the life of the adult. In practice, marriage is not restricted to the adult; the girl-child may be forced into early marriage without recourse to her consent nor the consequences of such forced union. The imposition of a marriage partner upon a child means that the childhood is lost and never regained (UNICEF, 2001). When children are hurried through childhood, and rushed into taking on adult task (such as marriage at a very early age, the effects can be profound and long lasting (Awake 2003).

Bayisenge (2010) noted that young girls are robbed of their youth and required to take on roles for which they are not psychologically or physically prepared. Many have no choice about the timing of marriage or their partner. Some are coerced into marriage, while others are too young to make an informed decision. Premature marriage deprives them of the opportunity for personal development as well as their right to full reproductive health, and well being $\&$ participation in Civic life.

\section{What Is Early Marriage}

The term early marriage or child marriage refers to any marriage of a child younger than 18years old in accordance to Article of the Convention on the Rights of the child. UNICEF (2005) describes it as both formal marriage and informal unions in which a girl lives with a partner as if married before the age of 18. It can also be defined as any marriage carried out below the age of 18 years, 
before the girl is physically, physiologically and psychologically ready to shoulder the responsibilities of marriage and child bearing.

Some scholars and activists have argued that instead of looking for a universal age at which girls and boys should marry, the focus should be put instead on eliminating the unwanted effects of early marriage (Women's human rights resources, http://www.law-lib.utoronto.ca/diana/ index.htm). The argument is that societal understanding of what it means to be a child differs. The situation in the regions of Africa tends to support this argument.

Lefevre (2004) states that while more women are now marrying at later age, early marriage remains a norm in sub-saharam Africa and South Asia. Over all, 20-50 per cent of women are married by the age of 18 in these regions. Bayisenge (2010) observed that African women in general marry at a much earlier age than their non-African counterparts, leading to early pregnancies. The Health Demographic Survey (HDS) for 1995 to 2003 shows that in Niger, 47 percent of women aged between 20 and 24 were married before the age of 15, and 87 percent before the age of 18, a total of 53 percent had also had a child before the age of 18 .

Bayisenge (2010) provided data on child marriage prevalence in 11 African countries that suggest a normative situation. The countries include: Niger (77 percent), Chad (71 percent), Mozambique (57 percent), Guinea (65 percent), Mah (65 percent), Uganda (54 percent), Burkina Faso (52 percent). Ethiopia, Togo and South Africa had prevalence rates of 49 percent 31 percent and 8 percent respectively.

Reports from IRIN Africa (2008) indicate that in Northern Nigeria, an estimated more than half of the girls are married before age 15. Among Nigerians predominantly Muslim northern states, only Jigawa state has passed a Law to enforce the UN Child Rights Act, which prohibits child marriage. The 2007 law itself does not specify an age, referring only to "puberty" to please the people. The law itself has never been enforced. In 2010, a Nigerian Senator was reported by the news media to have married a 13-year-old Egyptian girl. The report generated opprobrium in various circles but soon died down. The lesson learnt is that implementation of relevant laws are still a far cry from expectations in Nigeria.

\section{Reasons Behind Early Marriage}

Several reasons may be adduced for early marriage of the girl-child.

\subsection{Economic Reason}

Poverty has been identified as one of the major causes of early marriage. Where poverty is cute, a young girl may be regarded as an economic burden (UNICEF, 2001). Poverty is a critical factor contributing to child marriage and a common reason why parents may encourage a child to marry, in belief that such marriage may ring both financial and social gain to the family. The Forum of Marriage and the Rights of Women and Girls, 2001 provides the following case of a Zimbabwean girl who was married off at a very young age due to economic constraints. In August 2001, a tenyear-old girl in Zimbabwe was reportedly sold to a 40-year-old man as wife in order for the family to obtain cash for food.

\subsection{Socio-Cultural and Religious Values}

In societies, where early marriage is prevalent, there is strong pressure on families to conform. The old notion of an ideal age for marriage, the desire for submissive wives, and other customary requirement are all enshrined in local customs or religious norms (Bayisenge, 2010).

In the northern part of the country, religion plays major part in perpetuating early marriage. In the southern part of Nigeria, where the extended family system is strong, the influence of relations in early marriage phenomenon cannot be over-emphasized. 


\subsection{Notions of Morality and Honour}

It has been suggested that the dominant notion of morality and honour are important factors encouraging the practice of child marriage. The importance of maintaining family honour and the high value placed on virginity. Pregnancy outside marriage is not welcome in many societies. Yet, giving the prevalence of teen pregnancy, may societies settle for early marriage for girls. Awake (2004) reports that 31,857 children between 10 and 14 years of age gave birth in Brazil in 1998; in Britain, 90 percent of teenage births in 1997 born outside marriage; while in the United States, 4 in 10 teenage girls get pregnant at least once before they reach the age of 20 .

\section{Effects of Early Marriage}

Early marriage is associated with certain consequences which include physical, developmental, psychological and social implications.

\subsection{Physical Health Effects}

Early marriage subjects the girl-child to an early sexual experience with her husband. At an age where the bride is not physically and sexually mature, this has severe health consequences. It is reported that the worldwide incidence of premature birth and low birth weight is higher among adolescent mothers (http://wikipedia.org/wiki/Teenage-pregancy).

Bayisenge (2010) stated that the young married girls are under tremendous pressure to prove their fertility in the first year of marriage. They therefore have children early. UNICEF (2005) states that there is a strong correlation between the age of a mother and maternal mortality. Girls ages 10-14 are five times more likely to die in pregnancy or child birth than women aged 20-24 and girls aged 15-19 are twice as likely to die. There is also the problem of heavy bleeding during child birth and the Vesico Vaginal Fistula (VVF) ravaging young girls in some parts of Northern Nigeria.

Moreover, the age difference between the girl and her husband tends to reinforce the powerlessness of the girl. She is therefore at greater risk of abuse and less likely to assert herself.

Bayisenge (2010) noted that young married girls are more likely to be beaten or threatened and more likely to believe that a husband might sometimes be justified in beating his wife. The International Center for Research on Women (ICRW, 2008) reports that in Egypt 29 percent of married adolescents were beaten by their husbands. Of these, 41 percent were beaten when they were pregnant.

\subsection{Psychological and Social Effects}

Girls are not adequately prepared for the roles expected of them in the family. This therefore becomes a burden and has serious impact on their psychological welfare, their perception of themselves and also their relationship.

Early marriage can lead to psychological disadvantage which is a psychological development in and interaction with a social environment. Early marriage leads to less of freedom and a feeling of isolation for the girl-child as well as an unhappy marriage.

\subsection{Denial of Education}

Early marriage results to school-drop-out and its chain effects. In Northern Nigeria, 12 million girls aged around 13-14 are married in the region (IRIN Africa, 2008). The denial of education reduced such girls to that of dependence and subservience. Fairaa (2007) states that the gender inequality present in all aspects of society, including education leads to girls often lacking life skills and negotiating power. 
Husbands of young wives are often older man who expects their wives to follow tradition, stay home and undertake household and childcare duties. The thought of continuing schooling is often lost. Schools often have a policy of refusing to allow married or pregnant girl or girls to return. Even if they do not permit girls with babies to return, the school environment rules, time tables and physical conditions can make it difficult for a girl to attend school and perform her duties as wife and mother at the same time. Early marriage subsequently undermines the Millennium Development Goals ( 2 and 3 ) that seeks to achieve universal primary education, and promote gender equality and empower women.

This also affects, not only the health of the child of the illiterate mother, but the child's all round development (UNICEF, 2001). A study by Treffgarne (2002) found association between maternal literacy and school child's academic achievement. A longitudinal study by Burchfield R, Rumar P. \& Resser, M et al (2002) also supports that literate women are more aware of health and reproductive issues and the importance of children's education.

But early marriage limits girls' educational opportunities. Lioyd and Mensch (2006) found that "early marriage is more likely to limit girls' educational opportunities than early childbirth".

\section{Conventions on Early Marriage}

Child marriage is viewed as a violation of human rights and is prohibited by a number of international conventions and other instruments. Some of the instruments are paraphrased for clarity.

\subsection{Universal Declaration of Human Rights 1948}

Article 16 (1) of UDHR states that men and women of full age have the right to marry and found a family. They are entitled to equal rights as to marriage and its dissolution (2) Marriage shall be entered into only with the free and full consent of the intending parties.

\subsection{Convention on Consent to Marriage, Minimum Age for Marriage and Registration of Marriages, 1964}

Article 1 states that no marriage shall be legally entered into without the full and free consent of both parties, such consent to be expressed by them in person as prescribed by law. Article 2 states that parties to the present convention shall specify a minimum age for marriage.

\subsection{African Charter on the Rights and Welfare of the Child, 1990}

The Article XX1 states that child marriage and the betrothal of girls and boys shall be prohibited and effective action, including legislation, shall be taken to specify the minimum age of marriage to be eighteen years.

\subsection{Convention of the Rights of the Child, 1989}

A number of articles within the CRC hold relevance to child marriage. These include Articles 3, 19, $24,28,29,34$ and 36 . These are meant to protect the child against sexual exploitation and to hold the interest and welfare of the child prominent in all decisions. 


\section{Education as an Antidote to Early Marriage}

Early marriage is an issue that cannot be solved in isolation because it results from a complexity of social, cultural and economic dimensions and widespread gender discrimination. The causes and effects of child marriage are intrinsically linked.

Repeated studies have shown the importance of education in eliminating child marriage (Lioyd and Mensch 2006). The research by UNICEF (2004) shows that the more education a girl receives, the less likely she is to be married early. Improving access to education and eliminating gender gaps in education are important strategies for ending the practice of early marriage.

Government should exercise the political will to implement relevant laws and conceptions, including the right of the child as bona-fide citizen of the country. "Birth marriage and death are the standard frio of key events in most people's lives. But only one - marriage - is a matter of choice" (www.hsph.havard.edu/grhf/sasia/forums/child). No child should be denied the right to exercise this choice which should be done on due time.

Aside: Finally, while we as teachers ask for minimum wage, let us equally advocate the minimum age.

\section{Conclusion}

Early marriage still thrives in spite of various conventions against the practice. Although reasons often adduced in favour of the practice may appear attractive on face value, the physical health and psychological consequences of early marriage can constitute a huge price; in order to stem the tide of early marriage and its consequences, education of the girl-child must take pre-eminent position.

\section{References}

Awake (2003) Children: Are they growing up too Fast. New York: Watchtower Bible and Tract Society Inc. April 22.

Awka (2004) Teen pregnancy: A Global Tragedy New York: Watchtower Bible and Tract Society Inc. October 8.

Bayisenge, J. (2010) Early Marriage as a Barrier to Girl's Education Rwanda: Department of Social Sciences: National University of Rwanda.

Burchfield R, Rumar P. and Resser M. (2002) A Longitudinal Study on Effects of Literacy Programme on Rural Women in report 1d21 Insights Education, 7:2-5; UR:DFID.

Early Marriage Problems. Accessed on 28th April 2012 at http://wikipedia.org/inki/teenagepregancy.

Fairaa, E. (2007) Early Marriage and Education Newsletter, 7, EENET, mnt.

Forum on Marriage and the Rights of Women and Girls (2001) Early Marriage and Poverty Exploring Links for Policy and Programme Development London: Forward.

International Center for Research on Women (ICRN) (2008) Too Young to Wed, Child Marriage in the own Words Washington, DC.

IRIN Africa (2008) Nigeria: Early Marriage adds to Socioeconomic woes; Accessed on 28th April 2012 at www. irinafrica.org/earlymarriagenews.

Lefevre, J. (2004) future options foreclosed: Girls who Marry Early. Early Marriage Child Spouses, N.Y USA: UNICEF.

Lloyd, C.B. and Mensch, B.S. (2006) Marriage and Childbirth as factors in School Exit: An Analysis of DHS Data from sub-saharam Africa. Population Council 219, Accessed at www. popcouncil.org/dfs/wp/219.pdf on 28th April 2012.

Treffgarne, T.N. (2002) Maternal Literacy and Child's Academic Achievement. 1d21 Insights 6, 1-3. UR: DFID.

Undar (1945) Accessed on www.unicef-icdc.org/publication/pdf/digest7e.pdf

UNICEF (2001) Early Marriage: Child Spouses Accessed on 28th April 2012 at www.unicef.org/childmarriage. 
UNICEF (2005) Early Marriage: A Harmful Traditional Practice. Accessed on 28th April 2012 at www.unicef.org/childmarriage.

Women's Human Rights Resources. Accessed on 28th April 2012 at http://www.lawlib.utoronto.ca/diana/index.htm. 